\title{
A Proposed Framework Model of the Relationship between Organizational Culture, Work Engagement, and Employee Performance at Airasia Berhad
}

\author{
Md Murad Miah \\ MSc in Business Management, Faculty of Business Management \\ Universiti Teknologi MARA (UiTM), 40450 Shah Alam, Selangor \\ E-mail: muradmiah1996@gmail.com
}

Dr Nor Intan Adha Hafit

Faculty of Business Management, Universiti Teknologi MARA (UiTM)

40450 Shah Alam, Selangor

Received: August 1, 2019 Accepted: August 25, 2019 Published: October 27, 2019

doi:10.5296/ber.v9i4.15712 URL: https://doi.org/10.5296/ber.v9i4.15712

\begin{abstract}
The aim of this research to determine the relationship between organizational culture (OC) and employee performance (EP) mediated by work engagement (WE); and to make the proposed conceptual model on these three variables based on the prior literature review. In addition, this research focuses on airline business (AirAsia Berhad) which is one of the most famous and affordable airline companies in the Asia region. From the secondary data of AirAsia Berhad, it is demonstrated that for AirAsia succeed and to be a leading airline organization in Asia, employees are the main asset and contributor for succeed goal with a competitive advantage. Research has shown that AirAsia Berhad comes to this position due to the supported of leadership, organizational culture, employee's engagement and overall relay on employee's performance. However, the contribution of this study is two way explainable; one is theoretically - first of all, this research is proven the relationship among these three variables (OC, WE, EP) and determined the mediator role of work engagement between organizational culture and employee performance. Secondly, this research is developed the conceptual framework supported the previous literature that will facilitate the researcher for further study on this field. Another way is practical- this research will help the superior manager to induce plan to manage employees to succeed their goal with a competitive advantage. Secondly, it will help the manager to understood with concern; why employees
\end{abstract}


have to be compelled to engage and, why solid organizational culture is vital for work engagement and employee performance. Hence, this research is not out of limitation, which is described in the conclusion paragraph, consequently, these gaps need to fulfil by the future study.

Keyboards: Organizational Culture (OC), Work engagement (WE), Employee performance (EP), Motivation, Airasia Berhad

\section{Introduction}

In today's competitive business world, the keys to success in any business depend on innovation, organizational competitiveness, and overall organizational performance. To determine the keys to success in the organization, employees are one of the fundamental resources that helps a lot to achieve it. In addition, for organizational innovation, creativity is must needed things that comes from employees. Other than that, for organizational competitiveness, employees are the one who internal resource of the organization that cannot be duplicated by the rivals. The organizational performance is also more reliable with employee engagement, work culture, and employee performance. However, employees are the interior customer of each business, but innumerable organization fail to comprehend it. other than that, most of the research demonstrated that employee is the valuable assets for an organization who ends up in organizational success by tributary their performance and innovativeness (Richardsen,2019; Robertson and Cooper, 2010; Bakker and Schaufeli, 2008).

Normally, worker performance is taken into account what is employee does and doesn't do. Additionally, employee performance enclosed the standard amount of output, presence of labour, accommodative and useful nature and timeliness of output (Zhang et al, 2019). According to the results of the study conducted by DeNisi and Pritchard (2006) on individual performance showed that the performance of the people cannot be verified. Similarly, they assert that organizations can use direct bonuses and rewards supported individual performance if employee performance is noticeable (DeNisi and Pritchard, 2006). According to (Ngwa et al, 2019; Bishop 1987,) investigated employee performance and disclosed that acknowledgment and recognition and reward of performance of employees direct the discrimination between employee productivity. Morale and productivity of employees are extremely influenced by the effectiveness of performance of an organization and its reward management system (Jain et al, 2015). To satisfy customers, firms do abundant effort however do not concentrate to satisfying workers. but the fact is that customer would not be satisfied till and unless employees are satisfied. Because, if employees are satisfied, they will do a lot of work thus ultimately customers are satisfied (Murad, 2018).

In the airline business, organizational performance is usually associated with worker service where service nearly totally depends on the employee's willingness and motivation that organization given to them. Therefore, employee performance in any organization or field is influenced by motivation as a result of if employees are impelled then they will work with more effort and by that performance will ultimately improve the organizational success still. (Murad, 2018). 


\section{Theoretical Framework}

Naido \& Martin (2014) examined the relationship between organizational culture (OC) and work engagement (WE) among 3000 permanent employees in ICT companies in South Africa. Where were using the random sampling method and result highlighted that there is a significant relationship between organizational culture (OC) and Work Engagement (WE). In addition, the findings of this study confirmed the previous research finding where other researchers also proved there was significant relationship organizational culture (OC) and work engagement (WE), (Alarcon, 2010; Greenidge, 2010; Shuck et al., 2011).

Shahzad at el (2013) analysed the relationship between organizational culture (OC) and employee performance (EP) among Software house employees in Pakistan were using $(\mathrm{N}=$ 100). Based on researchers study it is shown that there is a significant relationship between organizational culture (OC) and employee performance (EP).

Yongxing et al (2017) determined the relationship between work engagement (WE) and employee performance (EP) among business organization employees in China, where sampling was based on $(\mathrm{N}=1049)$ population and result shown that there is a significant relationship between work engagement (WE) and employee performance.

\section{Airasia Berhad and Employee Performance}

AirAsia Berhad is a well-established organization in Malaysia. It is listed on the Main Board of Bursa Malaysia Securities Berhad since 2004. AirAsia Berhad is a component of the AirAsia group, a world-famous affordable airline that operates intensive networks each domestically and internationally. AirAsia pioneered affordable airfares in Asia and is now currently the largest low fare, essential airline in Asia. It is conjointly one amongst the largest airlines in all of Asia in terms of passengers carried. AirAsia has conjointly been voted the World's Best affordable Airline in 2009 and 2010. The airline was established by a Malaysian conglomerate in 1993 and commenced operations in 1996. Below the leadership of Tony Fernandes, the airline is flying high, and their vision is to be the most important affordable airline in Asia in order that they can offer a low-cost service which will enable the three billion individuals to fly to more destinations across the region. Hence, their mission is to be the highest company to figure in, wherever staff is treated like family.

From the leadership of Tony Fernandes, AirAisa growing their profit and market very fast. From the financial report of AirAsia Bhd shown that year of 2014 Air Asia were profited 83 million and each year it's growing not in lack of profit scale. Additionally, the year of 2018 AirAsia has got to gain 1965 (million) net profit that is the highest net profit by the AirAsia Bhd ever. In the below, providing the statement table that has adopted from AirAisa own website regarding financial Statistics. 
Table 1. Financial report of AirAsia Bhd

\begin{tabular}{|l|l|l|l|l|l|}
\hline & 2014 & 2015 & 2016 & 2017 & 2018 \\
\hline Revenue & 5,416 & 6,298 & 6,846 & 9,710 & 10,638 \\
\hline Net total expenses & 4,590 & 4,702 & 4,780 & 7,549 & 9,419 \\
\hline Operating profit & 826 & 1,596 & 2,066 & 2,161 & 1,219 \\
\hline Profit before taxation & 23 & 215 & 1,705 & 2,088 & 1,335 \\
\hline Taxation & 60 & 326 & -86 & -516 & 360 \\
\hline Net profit & 83 & 541 & 1,619 & 1,571 & 1,695 \\
\hline
\end{tabular}

*above all amount is provided in Million (RM)

Source: https://ir.airasia.com

For these rapid growing employees are the most contributor and their utmost effort helps AirAsia Berhad to attain this sort of success. Chief executive Tony Fernandes aforesaid that employees are a company's Most valuable assets and each effort ought to be created to create them determine with the company. Other than that, he additionally expressed that employees are the most effective fundamental resource that offers AirAsia in this position in the Airline industry nowadays. Additionally, organizational culture and engagement facilitate employees to perform higher and impact the significant overall performance of AirAsia Berhad. Therefore, from the rapid performance of AirAsia and chief executive officer speech, it is proved that employee performance is essential to any organization to survive and succeed.

\section{Conceptual Framework}

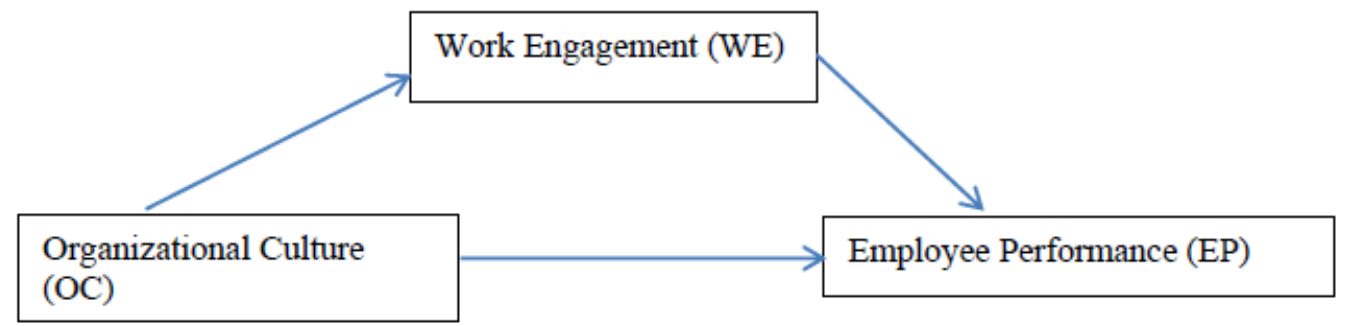

Figure 1. Conceptual Framework

\section{The Relationship between Organizational Culture (OC) and Work Engagement (WE)}

For decades, researchers have determined that an organization's culture ends up in a major competitive advantage within the business atmosphere (Naranjo-Valencia et al, 2016; Fortado \& Fadil, 2012). organizational culture (OC) is deed support as a predictive and explanatory construct in organizational studies (Fattah, 2017; Liu, Shuibo \& Meiyung, 2006), and has been coupled to job satisfaction and commitment (Yousef, 2017), and appears to be a central determinant of overall organizational effectiveness (Naranjo-Valencia et al, 2016). The ever present and pervasive nature of an organization's culture demands that organizations establish 
the elemental dimensions of their organizational culture and the impact therefrom on employee-related variables, like work engagement.

Employees' work engagement seems to be a decent indicator of outcomes that a business values, and is so a good measuring instrument of organizational health (Rana et al, 2019; Rich, Lepine, \& Crawford, 2010), and has been shown to be powerfully coupled to a spread of business success outcomes, as well as commitment, satisfaction, productivity, innovation, and retention, and, in general, positive work outcomes (Richardsen, 2019; Halbesleben, 2010). Work engagement is measured at the individual level, however, there clearly are organizational (i.e. culture, leadership, etc.) factors which will influence an employee's work engagement levels (Rich, Lepine, \& Crawford, 2010).

Other than that, the link between organizational culture and work engagement is explained from the social exchange theory (SET) perspective. consistent with the theory, social behaviour is the result of an exchange process. In his seminal writing on social exchange, Homans noted that "Social behaviour is an exchange of products (Adams, 1965). Thus, once staff understand the culture of the organization permits them to own a decent relationship with other members at intervals the organization, wherever they need the required support and power among others, they tend to relinquish their all, be dedicated and work with vigour.

\section{H 5: There is a significant relationship between Organizational culture (OC) and work engagement (WE)}

\section{The Relationship between Organizational Culture (OC) and Employee Performance} (Ep)

Organizational culture is considered as the character of the organization and it is the part of the shapes the manner in which the organizational capacities. It involves the frames of emotions, encounters, beliefs, and estimations of the organization, gained through social realizing, that control the manner in which people and groups in the organization interface with each other and with groups outside it. Besides, culture features consideration on the human sides of the hierarchical life stressing on the significance of making proper frameworks to empower employees to cooperate in accomplishing a shared objective.

As per Anitha (2014) the way to great execution is a solid culture. He likewise expressed that because of the social contrasts in authoritative culture, similar procedures do not yield similar outcomes for two organizations in a similar industry and a similar area. However, a positive and solid culture can cause a normal individual to perform and accomplish splendidly though a negative and feeble culture can demotivate extraordinary workers to fail to meet expectations and end up with no accomplishment. In this way, authoritative culture directly affects execution of the executives. (Murphy and Cleveland 1995) the belief that examination on culture will contribute to understanding the execution of the executives. According to the Baloch, Nadeem, and Zia-ur-Rehman, (2019) battles that without thinking about the effect of authoritative culture, hierarchical practices, for example, performance of the executives could be counterproductive in light of the fact that two are free and change in one will affect the other. 
H 6: There is a significant relationship between organizational culture (OC) and employee performance (EP)

\section{The Relationship between Work Engagement and Employee Performance}

Work engagement is a functioning, positive work-related state that is described by vigour, devotion, and ingestion (Bakker and Schaufeli, 2008; Simpson \& Michelle, 2009). Vigour alludes to elevated amounts of vitality and flexibility in work. Engagement is portrayed by solid inclusion in one's work just as a feeling of importance and energy. Retention is a condition of being completely thought and cheerfully immersed in one's work. Consequently, drew in employees are generally furnished with large amounts of vitality and excitedly engaged with their work. In addition, they are regularly completely submerged in their work with the goal that time flies (May, Gilson, and Harter, 2004) Work engagement is basic for organizations since it adds to the bottom line (Demerouti and Cropanzano, 2010; Macey $\&$ Schneider, 2008). Work engagement has been observed to be decidedly connected with employment execution appraised by bosses (Bakker and Bal, 2010; Halbesleben and Wheeler, 2008)

Work engagement is advantageous for both employees and organizations in light of the fact that drew in workers are relied upon to show better job performance. (Demerouti and Cropanzano, 2010). Better execution among connected employees, in contrast with nonconnected employees, is represented by connected workers' certain feelings, for example, joy, happiness, and eagerness (Bakker and Demerouti, 2008). engaged employees frequently experience positive feelings (Schaufeli and Van Rhenen, 2006). Cheerful individuals are progressively touchy to circumstances at work, all the more friendly and supportive to other people, and increasingly certain and idealistic (Yongxing et al, 2017). For instance, Bakker and Bal (2010) demonstrated that engaged teacher got higher appraisals from their bosses on in-job execution, showing that connected with workers perform well and are happy to go the additional mile. Salanova et al. (2005) directed an investigation among staff working in Spanish cafés and lodgings in which 342 employees gave data about organizational resources, engagement, and service climate and 1140 customers assessed workers' performance and revealed their own customer steadfastness. This exploration demonstrated that organizational resources and work engagement anticipated service climate, which thusly anticipated worker execution and customer loyalty. Besides, Xanthopoulou et al. (2009) directed research consider among employees working in a Greek drive-through eatery and found that day-levels of work engagement were prescient of target day by day monetary.

\section{$H$ 7: There is a significant relationship between work engagement and employee performance}

\section{Conclusion}

In this research, deeply concentrates on proposed conceptual model among organizational culture (OC), work engagement (WE) and employee performance (EP). Additionally, based on the review of existing literature it is proven that there is a significant relationship between organizational culture (OC) and work engagement (WE), organizational culture and 
employee performance (EP), work engagement (WE) and employee performance (EP) and mediation role of work engagement between organizational culture and employee performance.

Other than that, there is concentrate on an explicit organization that is Airline business (AirAsia Berhad). From the secondary, it is highlighted that AirAsia Berhad gains its competitive advantage and net profit increasing day by day supported leadership, organizational culture, employee's engagement with the organization, and due to the overall sensible management style.

Furthermore, the contribution of this study is two way explainable; one is theoretically - first of all, this research is proven the relationship among these three variables (OC, WE, EP) and determined the mediator role of work engagement between organizational culture and employee performance. Secondly, this research is developed the conceptual framework supported the previous literature that will facilitate the researcher for further study on this field. another way is practical- this research will help the superior manager to induce plan to manage employees to succeed their goal with a competitive advantage. Secondly, it will help the manager to understand with concern; why employees have to be compelled to engage and, why solid organizational culture is vital for work engagement and employee performance.

On the other hand, this research is not out of limitation; there are few limitations that require to concentrate on further research by other researchers. First, this research simply developed the conceptual framework supported previous literature review but ought to examine the connection and conceptual model. Secondly, due to the short time of research on this topic might a number of the current journal is not within the list of citation and reference, future research can concentrate on it. apart from that, this research simply concentrates on just one organization than the whole industry. Consequently, future research will concentrate on numerous organizations to examine the connection and examined the conceptual model. Lastly, this research entirely supported secondary data future can concentrate on both primary and secondary data or primary data.

Therefore, this research tries to fulfil the previous gaps and to provide new findings on the management field, however, researcher anticipates future research also fulfil the gaps of this research.

\section{References}

Adams, J. S. (1965). Inequity in social exchange. Advances in experimental social psychology, 2, 267-299. https://doi.org/10.1016/S0065-2601(08)60108-2

Alarcon, G., Lyons, J. B., \& Tartaglia, F. (2010). Understanding predictors of engagement within the milita ry. Military Psychology. https://doi.org/10.1080/08995605.2010.492695

Anitha, J. (2014). Determinants of employee engagement and their impact on employee performance. International journal of productivity and performance management, 63(3), 308. https://doi.org/10.1108/IJPPM-01-2013-0008 
Bakker, A. B., \& Bal, M. P. (2010). Weekly work engagement and performance: A study among starting teachers. Journal of occupational and organizational psychology, 83(1), 189-206. https://doi.org/10.1348/096317909X402596

Bakker, A. B., \& Demerouti, E. (2008). Towards a model of work engagement. Career development international, 13(3), 209-223. https://doi.org/10.1108/13620430810870476

Bakker, A. B., \& Schaufeli, W. B. (2008). Positive organizational behavior: Engaged employees in flourishing organizations. Journal of Organizational Behavior: The International Journal of Industrial, Occupational and Organizational Psychology and Behavior, 29(2), 147-154. https://doi.org/10.1002/job.515

Baloch, T., Nadeem, M. S., \& Zia-ur-Rehman, M. (2019). Impact of Employees Core Self-Evaluations on Employee Engagement: Moderating Role of Organizational Culture. Review of Economics and Development Studies, 5(2), 303-314.

https://doi.org/10.26710/reads.v5i2.538

Bishop, J. (1987). The recognition and reward of employee performance. Journal of Labor Economics, 5(4, Part 2), S36-S56. https://doi.org/10.1086/298164

Demerouti, E., Cropanzano, R., Bakker, A., \& Leiter, M. (2010). From thought to action: Employee work engagement and job performance. Work engagement: A handbook of essential theory and research, 65, 147-163.

DeNisi, A. S., \& Pritchard, R. D. (2006). Performance appraisal, performance management and improving individual performance: A motivational framework. Management and organization review, 2(2), 253-277. https://doi.org/10.1111/j.1740-8784.2006.00042.x

Fattah, A. H. (2017). The effect of organizational culture, leader behavior, self-efficacy, and job satisfaction on job performance of the employees. Jurnal Terapan Manajemen dan Bisnis, 3(2), 102-110. https://doi.org/10.26737/jtmb.v3i2.212

Fortado, B., \& Fadil, P. (2012). The four faces of organizational culture. Competitiveness Review: an international business journal, 22(4), 283-298.

https://doi.org/10.1108/10595421211247132

Greenidge, S. A. (2010). Leadership communication, culture and employee engagement: A correlation study (Doctoral dissertation), Phoenix, University of Phoenix.

Halbesleben, J. R. (2010). A meta-analysis of work engagement: Relationships with burnout, demands, resources, and consequences. Work engagement: A handbook of essential theory and research, 8(1), 102-117.

Halbesleben, J. R., \& Wheeler, A. R. (2008). The relative roles of engagement and embeddedness in predicting job performance and intention to leave. Work \& Stress, 22(3), 242-256. https://doi.org/10.1080/02678370802383962

Jain, A. K., \& Moreno, A. (2015). Organizational learning, knowledge management practices and firm's performance: an empirical study of a heavy engineering firm in India. The 
Learning Organization, 22(1), 14-39. https://doi.org/10.1108/TLO-05-2013-0024

Liu, A. M., Shuibo, Z., \& Meiyung, L. (2006). A framework for assessing organisational culture of Chinese construction enterprises. Engineering, Construction and Architectural Management, 13(4), 327-342. https://doi.org/10.1108/09699980610680153

Macey, W. H., \& Schneider, B. (2008). Engaged in engagement: We are delighted we did it. Industrial and Organizational Psychology, 1(1), 76-83.

https://doi.org/10.1111/j.1754-9434.2007.00016.x

May, D. R., Gilson, R. L., \& Harter, L. M. (2004). The psychological conditions of meaningfulness, safety and availability and the engagement of the human spirit at work. Journal of occupational and organizational psychology, 77(1), 11-37.

https://doi.org/10.1348/096317904322915892

Murad, M. M. (2018). The impact of employee job satisfaction toward organizational performance: A study of private sector employees in Kuching, East Malaysia. International Journal of Scientific and Research Publications (IJSRP), 8(12).

http://dx.doi.org/10.29322/IJSRP.8.12.2018.p8437

Murphy, K. R., \& Cleveland, J. N. (1995). Understanding performance appraisal: Social, organizational, and goal-based perspectives. Sage.

Naidoo, P., \& Martins, N. (2014). Investigating the relationship between organizational culture and work engagement. Problems and perspectives in management, 12(4), 433-441.

Naranjo-Valencia, J. C., Jiménez-Jiménez, D., \& Sanz-Valle, R. (2016). Studying the links between organizational culture, innovation, and performance in Spanish companies. Revista Latinoamericana de Psicología, 48(1), 30-41. https://doi.org/10.1016/j.rlp.2015.09.009

Ngwa, W. T., Adeleke, B. S., Agbaeze, E. K., Ghasi, N. C., \& Imhanrenialena, B. O. (2019). Effect of Reward System on Employee Performance among Selected Manufacturing Firms in the Litoral Region of Cameroon. Academy of Strategic Management Journal, 18(3).

Rana, S., Pant, D., \& Chopra, P. (2019). Work Engagement and Individual Work Performance: Research Findings and an Agenda for Employee Relationships.

Rich, B. L., Lepine, J. A., \& Crawford, E. R. (2010). Job engagement: Antecedents and effects on job performance. Academy of management journal, 53(3), 617-635.

https://doi.org/10.5465/amj.2010.51468988

Richardsen, A. M. (2019). Work engagement: increasing employee well-being and organizational effectiveness. In Creating Psychologically Healthy Workplaces. Edward Elgar Publishing. https://doi.org/10.4337/9781788113427.00025

Salanova, M., Martínez, I. M., \& Lorente, L. (2005). ¿ Cómo se relacionan los obstáculos y facilitadores organizacionales con el burnout docente?: Un estudio longitudinal. Revista de Psicología del Trabajo y de las Organizaciones, 21(1-2), 37-54.

Schaufeli, W. B., \& Van Rhenen, W. (2006). Over de rol van positieve en negatieve emoties 


\section{Macrothink}

Business and Economic Research ISSN 2162-4860 2019, Vol. 9, No. 4

bij het welbevinden van managers: Een studie met de Job-related Affective Well-being Scale (JAWS) [About the role of positive and negative emotions in managers' well-being: A study using the Job-related Affective Well-being Scale (JAWS)]. Gedrag \& Organisatie, 19(4), 223-244.

Shahzad, F., Iqbal, Z., \& Gulzar, M. (2013). Impact of organizational culture on employees job performance: An empirical study of software houses in Pakistan. Journal of Business Studies Quarterly, 5(2), 56.

Shuck, B., Reio Jr, T. G., \& Rocco, T. S. (2011). Employee engagement: An examination of antecedent and outcome variables. Human resource development international, 14(4), 427-445. https://doi.org/10.1080/13678868.2011.601587

Simpson, M. R. (2009). Engagement at work: A review of the literature. International journal of nursing studies, 46(7), 1012-1024. https://doi.org/10.1016/j.ijnurstu.2008.05.003

Xanthopoulou, D., Bakker, A. B., Demerouti, E., \& Schaufeli, W. B. (2009). Reciprocal relationships between job resources, personal resources, and work engagement. Journal of Vocational behavior, 74(3), 235-244. https://doi.org/10.1016/j.jvb.2008.11.003

Yongxing, G., Hongfei, D., Baoguo, X., \& Lei, M. (2017). Work engagement and job performance: the moderating role of perceived organizational support. Anales de Psicología/Annals of Psychology, 33(3), 708-713.

https://doi.org/10.6018/analesps.33.3.238571

Yousef, D. A. (2017). Organizational commitment, job satisfaction and attitudes toward organizational change: A study in the local government. International Journal of Public Administration, 40(1), 77-88. https://doi.org/10.1080/01900692.2015.1072217

Zhang, J., Bal, P. M., Akhtar, M. N., Long, L., Zhang, Y., \& Ma, Z. (2019). High performance work system and employee performance: the mediating roles of social exchange and thriving and the moderating effect of employee proactive personality. Asia Pacific Journal of Human Resources, 57(3), 369-395. https://doi.org/10.1111/1744-7941.12199

\section{Copyright Disclaimer}

Copyright for this article is retained by the author(s), with first publication rights granted to the journal.

This is an open-access article distributed under the terms and conditions of the Creative Commons Attribution license (http://creativecommons.org/licenses/by/3.0/). 